\title{
Individual-level Employment Transitions in Rural Viet Nam
}

Quang-Thanh $\mathrm{Ngo}^{1}$, Thuy-Khanh Hong Thai ${ }^{2}$, Van-Tien $\mathrm{Cao}^{3}$, Anh-Tuan Nguyen ${ }^{1}$, Ngoc-Hieu Hoang ${ }^{1}$, Ngoc-Danh Nguyen ${ }^{3}$

${ }^{1}$ University of Economics and Law, Vietnam National University Ho Chi Minh City (VNU-HCM), Vietnam

${ }^{2}$ Nguyen Tat Thanh University, Ho Chi Minh City, Vietnam

${ }^{3}$ University of Economics Ho Chi Minh City, Ho Chi Minh City, Vietnam

\begin{abstract}
Structural transformation in rural areas is a key issue in economic development. While much of the literature on structural transformation has so far focussed on household- or commune levels or even higher aggregate levels, little is known about the individual member level. The paper aims at examining factors that affect the individual-level employment rural transitions in Viet Nam, namely: (1) nontransient farm; (2) positive transient farm; (3) out-of-wage transition; (4) transitory farm-household work; and (5) transitory wage-household work. By taking advantage of the Viet Nam Access to Resources Household Survey with data on 2,698 individuals for two years, 2008 and 2016, using multivariate probit models estimated by generalized structural equation method, we find that individual-level human capital and social capital are important factors affecting employment transition status in the rural area. In addition, changes in individual and household characteristics and local climate conditions at commune level are important to influence various types of employment transitions. These results have implications for the development policy on rural transition in developing countries, highlighting the importance of recognizing the positive aspects of changes in individual-, household-, and commune-levels for rural transformation. Promotion of education attainment is necessary at both individual- and householdlevel to spur the transition out of farming. Broadened policy mechanisms which support and encourage non-farm employment at the household level are also needed. Likewise, development initiatives that focus on increasing the human and social assets of the individual farmers and farming households are more likely to be successful in supporting livelihood diversification and reducing vulnerability.
\end{abstract}

\section{Keywords}

Individual-level employment transitions; non-transient farm (persistent farm); positive transient farm; out-of-wage transition; transitory farm-household work, transitory wage-household work; rural transformation.

Ngo, Q.-T., Thai, T.-K. H., Cao, V.-T., Nguyen, A.-T., Hoang, N.-H. and Nguyen, N.-D. (2020) "Individuallevel Employment Transitions in Rural Viet Nam", AGRIS on-line Papers in Economics and Informatics, Vol. 12, No. 1, pp. 73-91. ISSN 1804-1930. DOI 10.7160/aol.2020.120107.

\section{Introduction}

Structural transformation in rural areas is a key issue in economic development and may take place at several levels (see, for example, Ellis and Harris (2004); Lanjouw and Lanjouw (2001); Reardon et al. (2001)). At the micro-level, it can be the result of decision-making by individual households or even household members (see the most recent research, for example, Newman and Kinghan (2015)). On the other hand, at the aggregate level such as a commune or province, government policies can affect the direction and speed of transformation (see, for example, Ulrik (2015)).

While a large number of studies on structural transformation so far focuses on household or commune level or even higher aggregate level, for example, Barrett et al. (2001), Berdegué et al. (2001), Bezemer and Davis (2002), Coppard (2001), Davis (2003), Deininger and Olinto (2001), Lanjouw and Lanjouw (2001), and Tarp (2017), little is known about the individual member level (which is mostly due to a lack of suitable datasets). Households are differential by their members with different human, financial, and physical assets 
and economic activities involved and therefore by targeting at individual members of households as individual members of the rural society, policy can bring effective support to enhance the opportunities to participate into non-farm employment in the rural area.

This current study takes advantage of the Viet Nam Access to Resources Household Survey (VARHS) in 2008-2016 with intensive information on individual-level employment. The final dataset is compiled by using the individual identification in combination with the information on age and gender, besides the common use of household identification and results in 2,699 individuallevel observations in two years: 2008 and 2016. The current paper arms at examining factors that affect the individual-level employment rural transitions in Viet Nam. The current paper, thus, tries to examine the following research questions: (1) To what extent do individual characteristics determine patterns of structural transformation in the rural area at individual level in Viet Nam? and (2) What are the roles of changes in individual characteristics, household characteristics, and local climate conditions at commune level in determining patterns of structural transformation in the rural area at individual level in Viet Nam?

Our primary hypothesis is that: (1) individual characteristics play crucial roles in individual-level transition statuses, namely: (a) non-transient farm (or persistent farm: The one is in farming during the whole studied period), (b) positive transient farm (the one moves from agriculture to wage/ salary sector), (c) out-of-wage transition (the one moves out of wage/salary sector to farming or to household business), (d) transitory farm-household work (the one moves from household work to agriculture), and (e) transitory wage-household work (the one moves from household work to wage/salary sector); and (2) while initial individual characteristics have effects on individual-level transition status, changes in individual/household characteristics and local climate conditions at commune level also determine patterns of structural transformation at individual level in the rural area of Viet Nam.

In general, this research has two objectives. First, it aims to contribute to the literature of employment transformation at the individual levels (a)-(e) previously described. To date, there has been very little analysis of employment transformation at individual level. Second, it provides evidence to deepen understanding of structural transformation in Viet Nam, particularly the factors that determine individuals' movements into and out of the farming sector, moving into the wage/salary sector and household businesses and why some individuals remain in farming. It also points out the factors that determine individuals' movements into farming, wage/salary sector and household businesses.

The rest of the paper is organized as follows. Section 2 describes materials and the methods. Section 3 discusses the empirical results.

\section{Materials and methods}

\section{Data source and sampling}

The data on diverse aspects of rural employment were collected from VARHS datasets. VARHS is a result of a joint project conducted by the Central Institute for Economic Management (CIEM) of the Ministry of Planning and Investment (MPI), the Institute of Policy and Strategy for Agriculture and Rural Development (IPSARD), the Institute of Labour Science and Social Affairs (ILSSA), and the Development Economics Research Group (DERG) of the University of Copenhagen (CIEM, DOE, ILSSA, and IPSARD, 2009).

The VARHS focuses on building on the substantial database of markets of land, labour, and employment. The employment module consists of individuallevel information on types of jobs (i.e. farming, non-farm or non-agriculture), and information on demographic characteristics, education, occupation, and industry for all employed persons.

The VARHS was carried out in the rural areas of twelve provinces in Viet Nam: (1) four (ex-Ha Tay, Nghe An, Khanh Hoa and Lam Dong); (2) five (Dak Lak, Dak, Nong, Lao Cai, Dien Bien and Lai Chau); and (3) three (Phu Tho, Quang Nam and Long An). These three province groups represent the main geographical differences in Viet Nam (Figure 1). By using VARHS in five years 2008, 2010, 2012, 2014, and 2016, the research gains a dataset of 2,698 individuals in two years: 2008 and 2016. 


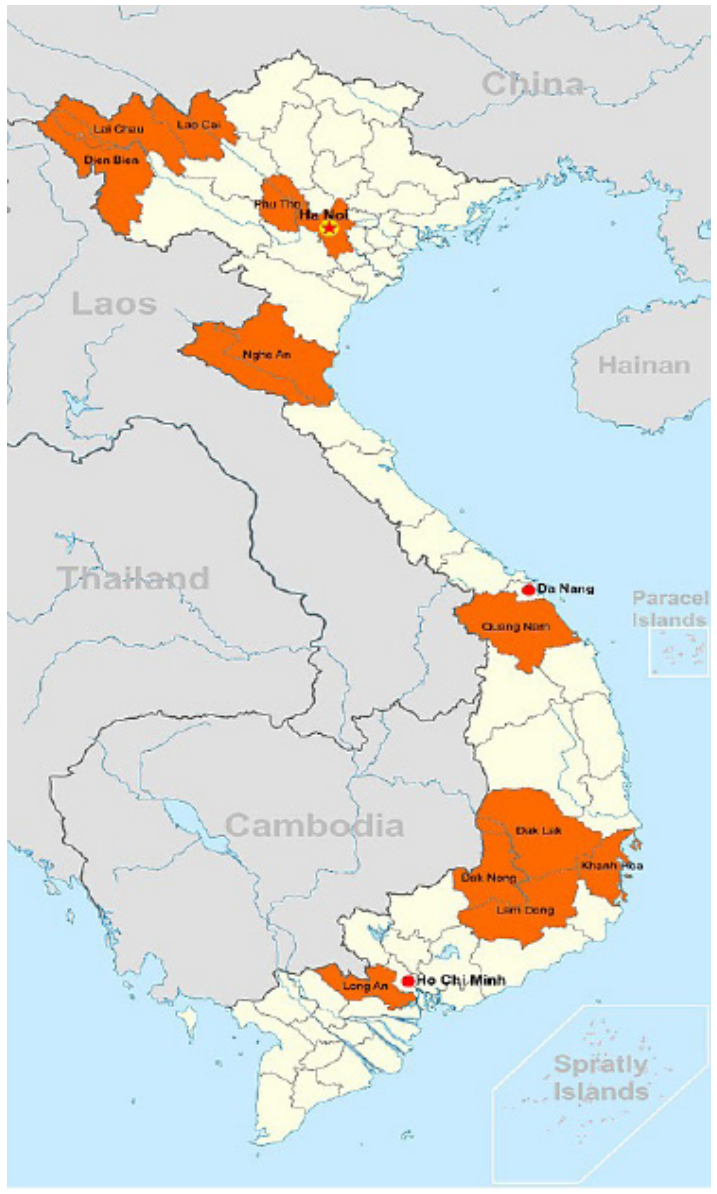

Source: Authors' creation

Figure 1: Site surveys.

From a truly unique five-wave panel of rural household-level dataset in 2008-16 with 2,131 observations in Viet Nam and a five-wave panel of rural commune-level dataset in 2008-2016 with 2,090 observations, we construct a sample of individual-level employment transitions in two years, 2008 and 2016, with 2,698 observations. The procedures are as follows:

Step 1: Separate individual-level datasets are created: 2008 (with 9,009 observations), 2010 (8,934), 2012 (8,379), 2014 (8,222), and 2016 (7,979 observations). Information includes position in the household, marriage status, gender, age, political-social membership, educational level, and employment status. Individual-level employment statuses include, exclusively: (1) wage/salary sector, (2) agriculture, (3) household business, (4) common properties resources. Individual-level employment statuses also includes: (5) household work, and (6) unemployed, which are not necessarily exclusive from each other. Household identification (including codes of province, district, commune, and household) is also kept.
Step 2: Using a combination of the age and gender as an individual identification, besides the common use of household identification, a consolidation of individual-level datasets with householdand commune-level dataset is conducted. At this stage, several yearly household identifications have been used and finally, a five-wave and individuallevel panel dataset with a maximized number of observations of 5,072 is obtained. The process goes further by dropping duplicated observations determined by a combination of household identification, individual identification, and age information in five waves of surveys, and the final five-wave and individual-level panel dataset have 4,611 observations. This dataset contains individuals who come from different households and belong to the same households as well.

Step 3: A sample of individual-level employment transitions between 2008 and 2016 is derived from the full set of five-wave and individual-level panel dataset of 4,611 observations. As a transitional stage, a sample including only individuals in 2008 who belong to one of these statuses: (1) farming, (2) household business, (3) wage/salary sector, and (4) household work, is refined and resulted in 2,698 observations. More detailed definitions of employment transitions are presented in the following section. The final dataset contains individuals who come from different households as well as individuals who belong to the same households.

\section{Methods}

\section{Definitions}

In our definition, employment includes: (1) working for a wage/salary sector outside the household; (2) participating in household production related to agriculture, forestry and aquaculture (or farm); (3) doing trading, services, transportation, or other business (self-employed) for the household (or non-farm, non-wage activities, not housework); (4) using common property resources to generate income for the household (hunting, fishing in the sea or lakes not on your property, gathering honey and berries, gathering forestry products etc.); and (5) doing housework or chores (cleaning, collecting firewood, washing clothes, cooking, etc.).

The current study follows the "spell" approach, which is widely used in poverty studies in identifying and measuring chronic and transient poverty (income- and consumption-based poverty) on the basis of panel data (Yaqub, 2000). The spell approach focuses on the number or length of spells 
of poverty experienced by households (Hulme and Shepherd, 2003).

The spell approach, in the current paper, is employed by categorizing employment transitions in rural Viet Nam as non-transient farm (or persistent farm, defined as an individual to be in agriculture throughout the survey period), positive transient farm (defined as a farming individual to be employed in wage/salary sector), out-of-wage transitory (defined as an individual to move from wage/salary sector to farming or to household business), transitory farm household work (defined as an individual to move from household work to agriculture), and transitory wage household work (defined as an individual to move from household work to wage/salary sector) (Table 1).

Figure 2 reports some summary statistics relating to individual's employment status for individuals included in the five-wave panel, treating the different waves as separate cross sections. The first column shows that the proportion of non-farm employment increases gradually over time with about 1.5 per cent per year. Income diversification and diversification of activities are important trends in rural of Viet Nam.

The next set of columns relates to the proportion of individuals involved in certain activities. A large majority of individuals work as farmers in each of the years. However, the proportion does decline gradually over time with about 2 per cent per year. In the third column, the proportion of working in wage/salary sector increases in the period of 2008-16 with about 2 per cent per year in the latest 3 years, namely 2012, 2014, and 2016. In the fourth column, the proportion of household enterprises increases in the period of 2008-16 with less than 1 per cent per year. In the fifth column, the proportion of engagement in common resource property decreases in the period of 2008-16 until nearly zero percent. The last column in Figure 2 relates to the percentage of unemployment with a decline of nearly 1 per cent per year during the period. In general, what is clear from Figure 1 is the importance of non-farm activities from the individual level. That in itself

\begin{tabular}{ll}
\hline Transition type & 2008-2016 \\
\hline (1) Non-transient farm (or persistent farm) & Being farm during the whole period \\
(2) Positive transient farm & From agriculture to wage/salary sector \\
(3) Out-of-wage transition & From wage/salary sector to farming or to HH business \\
(4) Transitory farm-household work & From household work to agriculture \\
(5) Transitory wage-household work & From household work to wage/salary sector \\
\hline
\end{tabular}

Source: Authors' compilation from VARHS 2008-2016. HH: Household

Table 1: Definition of transitions in the rural area.

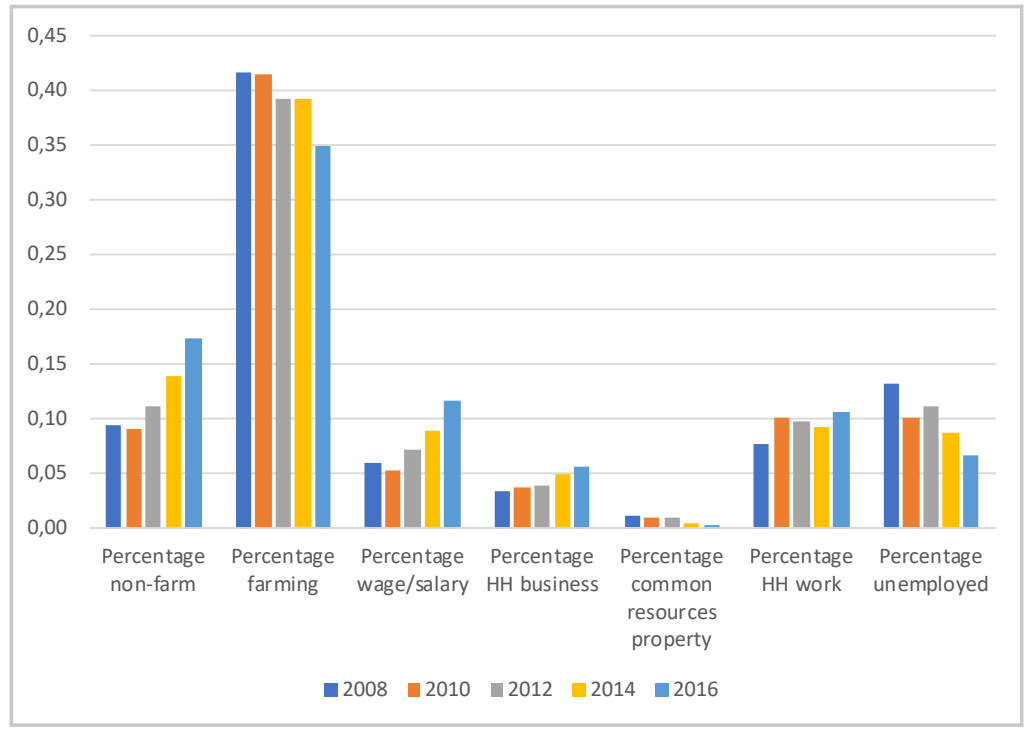

Source: Authors' calculation from VARHS 2008-2016

Figure 2: Statistic description of transition status, 2008-2016. 
is a signal of the success of rural transformation in Viet Nam. However, the analysis to date is only conducted at an aggregate level and does not exploit the panel features of the data set; the remainder of this paper now analyses these three activities separately and in more detail.

\section{Methods of analysis}

The current paper estimates factors associated with the individual-level employment transitions. The basic model is identified as follows (Model 1):

$\operatorname{Trans}_{i j k}=\left\{I N D I_{i}^{0} \alpha+\operatorname{INCOME}_{\mathrm{j}}^{0} \beta+\alpha_{k}+u_{i}+e_{i j k} \geq 0\right\}$

Where: the script ijk denotes individual $i$ in household $j$ and commune $k$. While 0 denotes the year 2008, 1 denotes the year 2016. $\alpha_{k}$ is cluster specific effect which change across clusters and it is assumed that $\alpha k \sim\left[0, \sigma_{\mathrm{k}}^{2}\right] . \varepsilon_{\mathrm{ijk}}$ has zero mean and constant variance, and $u_{i}$ is an individual specific fixed effect.

Trans is individual's transitions in the rural area as defined in Table 1, in which: 1 is non-transient farm (or persistent farm), 2 is positive transient farm, 3 is out-of-wage transition, 4 is 'transitory farm-household work', 5 is 'transitory wagehousehold work'.

INDI is a vector of individual characteristics in 2008, including marital status, age, and educational attainment, social capital (social network), according to Walter and Heinrichs (2015), Simoes et al. (2016), Liu and Liu (2016), Barrett et al. (2001), Coppard (2001), Deininger and Olinto (2001), Reardon et al. (2001), and Reardon (1997). A positive and significant association between education levels and non-farm income at individual level has been empirically established in different developing country contexts (see for example, Barrett et al. (2001); Coppard (2001); Deininger and Olinto (2001); Reardon et al. (2001)). Better educated individuals are likely to possess skills which facilitate successful involvement in non-farm activities, including the ability to manage a business, process relevant information, adapt to changing demand patterns, and liaise with public and private service providers. They are also likely to have greater aspirations with regard to working outside agriculture. Being married and having young children and elderly parents is likely to reduce the propensity of females participate in the labour market. Nevertheless, the availability of domestic help can enable mothers to go out to work. In contrast, being married, being heads of households, and having children and elderly parents are likely to compel males to participate in the labour market.
INCOME is household income in 2008 (Barrett et al. (2001); Coppard (2001); Deininger and Olinto (2001); Reardon et al. (2001); Reardon (1997)).

The factors affecting the probability of choosing a particular employment status could also affect the probability of choosing another type of employment. Consequently, the error terms of employment choice functions are correlated. This unique characteristic requires the application of the so-called seemingly (un)related regression models, which need to be jointly estimated from several regression models, where the error terms associated with the dependent variables are assumed to be correlated across the following equations. Therefore, the empirical basic model of employment transition includes a set of five simultaneous equations which can be further elaborated as follows:

$\left\{\begin{array}{l}\operatorname{Trans}_{i j k 1}=\left[\operatorname{Trans}_{i j k}=1\right]=I N D I_{i 1}^{0} \alpha+I N C O M E_{j 1}^{0} \beta+\alpha_{k}+u_{i}+e_{i j k 1} \\ \operatorname{Trans}_{i j k 2}=\left[\operatorname{Trans}_{i j k}=2\right]=I N D I_{i 2}^{0} \alpha+I N C O M E_{j 2}^{0} \beta+\alpha_{k}+u_{i}+e_{i j k 2} \\ \operatorname{Trans}_{i j k 3}=\left[\operatorname{Trans}_{i j k}=3\right]=I N D I_{i 3}^{0} \alpha+I N C O M E_{j 3}^{0} \beta+\alpha_{k}+u_{i}+e_{i j k 3} \\ \operatorname{Trans}_{i j k 4}=\left[\operatorname{Trans}_{i j k}=4\right]=I N D I_{i 4}^{0} \alpha+I N \operatorname{COM} E_{j 4}^{0} \beta+\alpha_{k}+u_{i}+e_{i j k 4} \\ \text { Trans }_{i j k 5}=\left[\operatorname{Trans}_{i j k}=5\right]=I N D I_{i 5}^{0} \alpha+I N C O M E_{j 5}^{0} \beta+\alpha_{k}+u_{i}+e_{i j k 5}\end{array}\right.$

(1-ALT)

Since dependent variables in model 1-ALT are discrete ones, we estimate model 1-ALT by using gsem (generalized structural equation model) command in Stata applied for multivariate probit models (Huber, 2013; Huber, 2014).

The second objective of the current study is to examine the roles of changes in individual characteristics, household characteristics, and local climate conditions at the commune level in determining patterns of structural transformation in the rural area at individual level in Viet Nam. Therefore, we seek for the effects of changes related to individual, household characteristics, and local climate conditions at the commune level between 2008 and 2016, respectively. A set of extension models of transitions in rural area are named as Models 1A, 1B, and $1 \mathrm{C}$ as follows:

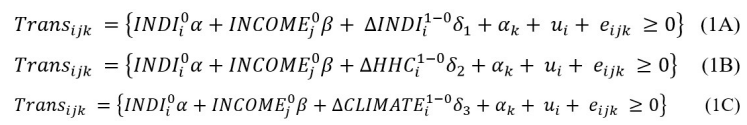

in which, $\triangle I N D I_{i}^{1-0}, \Delta H H C_{i}^{1-0}$, and $\triangle C L I M A T E_{i}^{1-0}$ are vectors of changes in individual characteristics (INDI), household characteristics (HHC), and local climate conditions (CLIMATE) at the commune level during 2008-2016, respectively. The initial variables represent the individual conditions $\left(I N D I_{i}^{0}\right)$ and changes in individual characteristics $\left(\triangle I N D I_{i}^{1-0}\right)$, changes in household characteristics $\left(\Delta H H C_{i}^{1-0}\right)$, and changes in local climate conditions 
$\left(\triangle\right.$ CLIMATE $\left._{i}^{1-0}\right)$ at the commune level as well may change the transition status in the future. For example, farms decide to be non-farms after changing their marital status or furthering their education. Meanwhile, a new policy issue might make the farms become non-farms.

HHC is a vector of household characteristics, including age of working-age members, the ratio of children, number of working-age members, and number of Vietnamese communist party member, shares of education levels among household members, social capital (social network), land endowments (land ownership in hectares), size of living house (in square meters), access to credit, and access to government transfer (see for example, Fafchamps and Minten (1998); Montgomery (1991); Rozelle et al. (1999); Banerjee (1983); $\mathrm{Wu}$ and Zhou (1996); Nee (1996); Bezemer and Davis (2002); Davis (2003); Coppard (2001); Rennings et al. (2001); Liu et al. (2018); Martin and Lorenzen (2016); Rigg et al. (2018); Sackey (2018)).

CLIMATE is a vector of the local climate conditions at the commune level, which is represented by the number of weather shocks (Doss et al. (2008); Povel (2015)) that the commune has experienced during the last three years (Barrett, 2014).

A similar operationalization as shown in model 1-ALT for extension models $1 \mathrm{a}, 1 \mathrm{~b}$, and $1 \mathrm{c}$ is conducted and we estimate the corresponding models, namely model 1A-ALT, 1B-ALT, and $1 \mathrm{C}-\mathrm{ALT}$.

\section{Results and discussion}

\section{Statistical description}

Table 2 presents an overall picture of rural transition during 2008-16, which is based on the 2,699 individuals in the five-wave panel between 2008 and 2016, looking in particular at the extent to which individuals move within a number of activities, namely: farming, wage, household business, and household work. While individuals persistently engaged in agriculture is dominant in the sample (16.30 percent), Table 2 shows variations of other activities by individuals. Individuals moving from agriculture to wage/salary sector account for 4.56 per cent, while moving to household work is 13.78 per cent in the sample. Similarly, individuals moving from wage/salary sector to household work also account for 13.78 per cent in the sample. Individuals moving from wage/salary sector to both farming and household business are about 3.78 per cent. During the period, there are 7.97 per cent of individuals moving from household to farming, and 3.74 per cent moving from household to wage/ salary sector, a little bit lower than the percentage of individuals moving from farming to wage/salary sector (4.56 percent).

Table 3 presents details of five forms of employment transition in the rural area in terms of individual characteristics in the initial year of 2008. In the following part, we compare possible employment transitions (from column 2 to 5) with persistent farming (in column 1).

Firstly, comparing persistent farming (column 1) and positive transient farm (column 2) in Table 3, we find that the former is less likely to be male, more likely to get married, more likely to be older, more likely to be the household head, and lives in a household with higher income per capita. Persistent farming (column 1) reports more probability to be a member of Farm Union. Membership in Communist Party of Vietnam (CPV) is likely to be the same between the two groups. Regarding education level, persistent farming (column 1) shows more probability to be 'unable to read and write', more likely to complete primary school, whereas positive transient farm (column 2) is more likely to finish upper secondary school, and can read and/or write (but never went to school) as well.

Secondly, like positive transient farm (column 2), 'out-of-wage' (column 3) shows more probability to be male, less likely to get married, less likely

\begin{tabular}{lcccccc}
\hline From & $\begin{array}{c}\text { To farming, } \\
\%\end{array}$ & $\begin{array}{c}\text { To wage/salary sector, } \\
\%\end{array}$ & $\begin{array}{c}\text { To HH business, } \\
\%\end{array}$ & $\begin{array}{c}\text { To HH work, } \\
\%\end{array}$ & $\begin{array}{c}\text { To other, } \\
\%\end{array}$ & $\begin{array}{c}\text { Total, } \\
\%\end{array}$ \\
\hline Farming & $16.30(440)$ & $4.56(123)$ & $1.37(37)$ & $13.78(372)$ & $63.99(1,727)$ & $100.00(2,699)$ \\
Wage/salary sector & $2.56(69)$ & $1.44(39)$ & $1.22(33)$ & $13.78(372)$ & $80.99(2,186))$ & $100.00(2,699)$ \\
HH business & $0.59(16)$ & $1.11(30)$ & $1.11(30)$ & $1.30(35)$ & $95.89(2,588)$ & $100.00(2,699)$ \\
HH work & $7.97(215)$ & $3.74(101)$ & $0.59(16)$ & $0.70(19)$ & $87.00(2,348)$ & $100.00(2,699)$ \\
\hline
\end{tabular}

Note: HH: household; Number of observations in parentheses

Source: Author's estimation from VARHS 2008-2016 


\begin{tabular}{|c|c|c|c|c|c|}
\hline Variable & $\begin{array}{c}\text { Persistent } \\
\text { farming }\end{array}$ & $\begin{array}{l}\text { Positive transient farm } \\
\text { (From agriculture } \\
\text { to wage/salary sector) }\end{array}$ & $\begin{array}{c}\text { Out-of-wage } \\
\text { (From wage/salary } \\
\text { sector to farming } \\
\text { or household business) }\end{array}$ & $\begin{array}{l}\text { Transitory farm-HH } \\
\text { work } \\
\text { (From HH work } \\
\text { to farming) }\end{array}$ & $\begin{array}{l}\text { Transitory wage-HH } \\
\text { work (From HH work } \\
\text { to wage/salary sector) }\end{array}$ \\
\hline & -1 & -2 & -3 & -4 & -5 \\
\hline $\operatorname{Sex}(=1)$ & 0.37 & $0.71 * * *$ & $0.60 * * *$ & 0.41 & $0.44 *$ \\
\hline Married (=1) & 0.88 & $0.35^{* * *}$ & $0.64 * * *$ & $0.44^{* * *}$ & $0.23 * * *$ \\
\hline Age (years) & 46.15 & $27.64 * * *$ & $34.70 * * *$ & $41.74 * * *$ & $26.27 * * *$ \\
\hline Age squared (years) & 23.00 & $9.58 * * *$ & $14.05 * * *$ & 23.78 & $12.40 * * *$ \\
\hline Head $(=1)$ & 0.38 & $0.20 * * *$ & 0.31 & $0.29 * *$ & $0.13^{* * *}$ \\
\hline Cannot read and write $(=1)$ & 0.11 & $0.04 * *$ & $0.02 * * *$ & 0.10 & 0.13 \\
\hline Completed primary $(=1)$ & 0.27 & $0.13^{* * *}$ & 0.17 & $0.38 * * *$ & $0.43^{* * *}$ \\
\hline Completed lower secondary $(=1)$ & 0.51 & 0.46 & $0.39 * *$ & $0.34 * * *$ & $0.34 * * *$ \\
\hline Completed upper secondary $(=1)$ & 0.11 & $0.33^{* * *}$ & $0.42 * * *$ & 0.12 & $0.06^{*}$ \\
\hline Can read and write but no school $(=1)$ & 0.01 & $0.03 *$ & 0.00 & $0.05 * * *$ & $0.04 * *$ \\
\hline CPV member $(=1)$ & 0.02 & 0.01 & $0.06^{* * *}$ & 0.02 & 0.01 \\
\hline In farmer group $(=1)$ & 0.16 & $0.07 * * *$ & $0.05 * * *$ & $0.07 * * *$ & $0.02 * * *$ \\
\hline Net total income per capita in $2008(\log )$ & 8.85 & $8.46^{* * *}$ & $9.24 * * *$ & $8.67 * * *$ & $8.57 * * *$ \\
\hline Number of observations & 437 & 123 & 110 & 372 & 216 \\
\hline
\end{tabular}

Note: HH: Household; $* * * \mathrm{p}<0.01, * * \mathrm{p}<0.05, * \mathrm{p}<0.1$; all are non-parametric two-sample test: Mann-Whitney U test and compared with column (1). Total sample: 2,698

Source: Author's estimation from VARHS 2008-2016

Table 3: Transition in rural area: Initial year in 2008 (Percentage).

to be older. However, 'out-of-wage' (column 3) proves more possibility to live in a household with higher income per capita. 'Being the household head' is likely to be the same between the two groups. Persistent farming (column 1) reports more probability to be a member of Farm Union, whereas 'out-of-wage' (column 3) shows more possibility to be a member of CPV. With respect to education level, persistent farming (column 1) reveal more probability to be 'unable to read and write', whereas 'out-of-wage' (column 3) is more likely to finish upper secondary school.

Thirdly, both 'transitory farm-household work' (column 4) and 'transitory wage-household work' (column 5), in comparison with persistent farming (column 1), inform a less probability of getting married, of being older, being the household head, being a member of Farmer Union, and possess a lower income per capita household membership. With regard to education level, both 'transitory farm-household work' (column 4) and 'transitory wage-household work' (column 5) itemize more probability to complete primary school, to be 'can read and write but never went to school', whereas less likely to finish lower secondary school.

Table 4 presents details of employment transitions in the rural area in terms of changes between 2016 and 2008. We compare possible employment transitions (from columns 2 to 5) with persistent farming (in column 1).
Firstly, regarding to changes in individual characteristics between 2016 and 2008, we find that persistent farming is less likely to get married than other four types of transition. In addition, there is no difference between persistent farming and other transition form in terms of 'being married', 'being divorced', and 'being CPV member'. While positive transient farm (column 2) and out-of-wage transition (column 3) are different from persistent farming in terms of 'completed lower secondary', 'transitory farm-household work' and 'transitory wage-household work' are different from persistent farmers in terms of 'completed upper secondary'. Being a member of Farmer Union is associated with both 'transitory farm-household work' and 'transitory wage-household work'

Secondly, with respect to changes in household characteristics between 2016 and 2008, change in household head leads to changes in four types of transition in comparison with persistent farming (column 1), while no matter what a change in CPV status of a household head or change in CPV member of a household, no transition of any type is observed. Regarding to demographic factors, increase in household size reports more probability to move out of wage/salary sector to either farming or household business (column 3). Timing effect of old age increases the probability to move from household work to either farming or wage/salary sector (columns 4 and 5). Higher 
dependency ratio has higher change to move out of wage/salary sector to either farming or household business (column 3), or to move from household work to either farming or wage/ salary sector (columns 4 and 5). Access to credit is found to be indifferent among types of employment transition. Changes in arable land increases the probability to move out of wage/salary sector to either farming or household business (column 3), whereas income increase is associated with a more possibility to be positive transient farm (column 2) or transitory wage-household work status (column 5). There is no difference in terms of assets such as durable asset value and housing size among types of transition. Political and social networks report a higher probability to be transitory wagehousehold work status (column 5). Natural and pest shocks are found to affect the move out of wage/ salary sector to farming or household business (column 3).

\begin{tabular}{|c|c|c|c|c|c|}
\hline \multirow[t]{2}{*}{ Variable } & $\begin{array}{l}\text { Persistent } \\
\text { farming }\end{array}$ & $\begin{array}{l}\text { Positive transient farm } \\
\text { (From agriculture } \\
\text { to wage/salary sector) }\end{array}$ & $\begin{array}{l}\text { Out-of-wage } \\
\text { (From wage/salary } \\
\text { sector to farming } \\
\text { or HH business) }\end{array}$ & $\begin{array}{l}\text { Transitory farm-HH } \\
\text { work (From HH work } \\
\text { to farming) }\end{array}$ & $\begin{array}{l}\text { Transitory wage-HH } \\
\text { work (From HH work } \\
\text { to wage/salary sector) }\end{array}$ \\
\hline & (1) & (2) & (3) & (4) & (5) \\
\hline \multicolumn{6}{|c|}{ Changes in individual characteristics (dummy), from No (in 2008) to Yes (in 2016) } \\
\hline Married & 0.01 & $0.13^{* * *}$ & $0.05^{* * *}$ & $0.03 * * *$ & $0.03 * *$ \\
\hline Divorced & 0.00 & 0.00 & 0.00 & 0.03 & 0.00 \\
\hline Head of $\mathrm{HH}$ & 0.02 & 0.00 & 0.01 & 0.02 & 0.01 \\
\hline Completed lower secondary & 0.04 & $0.01 *$ & $0.00 * *$ & 0.02 & 0.03 \\
\hline Completed upper secondary & 0.03 & 0.05 & 0.04 & $0.06^{*}$ & $0.13 * * *$ \\
\hline CPV member & 0.00 & 0.00 & 0.02 & 0.00 & 0.00 \\
\hline In farmer group & 0.07 & 0.03 & 0.04 & $0.01 * * *$ & $0.01 * * *$ \\
\hline \multicolumn{6}{|c|}{ Changes in household characteristics (dummy), from No (in 2008) to Yes (in 2016) } \\
\hline Head changed & 0.00 & $0.02 * * *$ & $0.01 * *$ & $0.01 * *$ & $0.03 * * *$ \\
\hline Head being CPV member & 0.01 & 0.00 & 0.02 & 0.00 & 0.00 \\
\hline Increase in primary degree & 0.22 & $0.14^{*}$ & 0.28 & 0.21 & 0.22 \\
\hline Increase in lower secondary degree & 0.40 & 0.37 & 0.35 & 0.39 & 0.46 \\
\hline Increase in upper secondary degree & 0.45 & $0.58^{* *}$ & 0.48 & $0.55^{* * *}$ & $0.62 * * *$ \\
\hline Increase in $\mathrm{HH}$ size & 0.23 & 0.26 & $0.39^{* * *}$ & 0.25 & 0.24 \\
\hline $\begin{array}{l}\text { Increase in average ages of working- } \\
\text { age members }\end{array}$ & 0.69 & 0.68 & 0.65 & $0.46^{* * *}$ & $0.46^{* * *}$ \\
\hline $\begin{array}{l}\text { Increase in numbers working-age } \\
\text { members }\end{array}$ & 0.25 & $0.37 * *$ & 0.28 & $0.59 * * *$ & $0.58 * * *$ \\
\hline Increase in the ratio of children & 0.28 & 0.30 & $0.43^{* * *}$ & $0.41 * * *$ & $0.12 * * *$ \\
\hline $\begin{array}{l}\mathrm{CPV} \text { member(s) (Counting the } \mathrm{HH} \\
\text { head) of } \mathrm{HH}\end{array}$ & 0.01 & 0.01 & 0.04 & $0.00 *$ & 0.00 \\
\hline $\begin{array}{l}\text { CPV member(s) (Not counting the } \mathrm{HH} \\
\text { head) of HH }\end{array}$ & 0.01 & 0.01 & 0.03 & 0.00 & 0.00 \\
\hline Access to credit & 0.01 & 0.02 & 0.02 & 0.01 & 0.00 \\
\hline Increased in arable land & 0.19 & 0.18 & $0.08 * * *$ & 0.18 & 0.22 \\
\hline Loss in arable land & 0.17 & 0.20 & 0.15 & $0.13^{*}$ & 0.17 \\
\hline Land per capita & 0.19 & 0.18 & $0.08^{* * *}$ & 0.22 & 0.22 \\
\hline Increased in income & 0.92 & $0.97 *$ & 0.88 & 0.91 & $0.88^{*}$ \\
\hline Increased in asset values & 0.19 & 0.20 & 0.16 & 0.21 & 0.23 \\
\hline Increased in housing size & 0.19 & 0.20 & 0.16 & 0.21 & 0.23 \\
\hline Political network member & 0.05 & 0.06 & 0.03 & 0.08 & $0.09^{*}$ \\
\hline Having support from relatives & 0.20 & $0.13^{*}$ & 0.17 & 0.19 & $0.09^{* * *}$ \\
\hline Natural shock & 0.06 & 0.04 & $0.01 * *$ & 0.05 & 0.07 \\
\hline Pest shock & 0.04 & 0.02 & $0.00^{* *}$ & 0.03 & 0.03 \\
\hline
\end{tabular}

Note: HH: Household; $* * * \mathrm{p}<0.01, * * \mathrm{p}<0.05$, ${ }^{*} \mathrm{p}<0.1$; all are non-parametric two-sample test: Mann-Whitney U test and compared with column (1). Total sample: 2,698

Source: Author's estimation from VARHS 2008-2016

Table 4: Transitions in rural area between 2008 and 2016 (Percentage) (to be continued). 


\begin{tabular}{|c|c|c|c|c|c|}
\hline \multirow[t]{2}{*}{ Variable } & $\begin{array}{c}\text { Persistent } \\
\text { farming }\end{array}$ & $\begin{array}{l}\text { Positive transient farm } \\
\text { (From agriculture } \\
\text { to wage/salary sector) }\end{array}$ & $\begin{array}{l}\text { Out-of-wage } \\
\text { (From wage/salary } \\
\text { sector to farming } \\
\text { or HH business) }\end{array}$ & $\begin{array}{l}\text { Transitory farm-HH } \\
\text { work (From HH work } \\
\text { to farming) }\end{array}$ & $\begin{array}{c}\text { Transitory wage-HH } \\
\text { work (From HH work } \\
\text { to wage/salary sector) }\end{array}$ \\
\hline & (1) & $(2)$ & (3) & (4) & $(5)$ \\
\hline Economic shock & 0.02 & 0.02 & 0.01 & 0.02 & 0.01 \\
\hline Illness shock & 0.02 & 0.02 & 0.01 & 0.02 & 0.01 \\
\hline \multicolumn{6}{|c|}{ Changes in commune characteristics (dummy), from No (in 2008) to Yes (in 2016) } \\
\hline Flood, t-1 & 0.08 & 0.13 & 0.05 & 0.10 & 0.10 \\
\hline Drought, $\mathrm{t}-1$ & 0.20 & 0.15 & 0.15 & 0.20 & 0.23 \\
\hline Typhoon, t-1 & 0.09 & 0.06 & 0.05 & 0.10 & 0.10 \\
\hline Land slide, $\mathrm{t}-1$ & 0.04 & $0.08 *$ & $0.01 *$ & 0.05 & 0.07 \\
\hline Animal/livestock epidemics, t-1 & 0.15 & 0.10 & 0.18 & 0.15 & 0.14 \\
\hline Plant disease, $\mathrm{t}-1$ & 0.11 & 0.11 & 0.15 & 0.07 & 0.07 \\
\hline Insects/rats, t-1 & 0.06 & 0.06 & 0.06 & 0.05 & 0.05 \\
\hline Flood, t-2 & 0.10 & 0.10 & 0.05 & 0.12 & 0.11 \\
\hline Drought, $\mathrm{t}-2$ & 0.16 & 0.11 & $0.06 * * *$ & 0.16 & $0.21^{*}$ \\
\hline Typhoon, t-2 & 0.12 & $0.07 *$ & 0.07 & 0.12 & 0.11 \\
\hline Land slide, $\mathrm{t}-2$ & 0.05 & $0.10^{*}$ & 0.03 & 0.03 & 0.07 \\
\hline Animal/livestock epidemics, $\mathrm{t}-2$ & 0.15 & 0.12 & 0.20 & 0.15 & 0.15 \\
\hline Plant disease, $\mathrm{t}-2$ & 0.10 & 0.09 & 0.15 & 0.07 & 0.08 \\
\hline Insects/rats, t-2 & 0.06 & 0.04 & 0.08 & 0.05 & 0.05 \\
\hline Number of observations & 437 & 123 & 110 & 372 & 216 \\
\hline
\end{tabular}

Note: HH: Household; *** $\mathrm{p}<0.01, * * \mathrm{p}<0.05, * \mathrm{p}<0.1$; all are non-parametric two-sample test: Mann-Whitney U test and compared with column (1). Total sample: 2,698

Source: Author's estimation from VARHS 2008-2016

Table 4: Transitions in rural area between 2008 and 2016 (Percentage) (continuation).

Thirdly, with respect to changes in local climate conditions between 2016 and 2008, most of natural disasters in the previous year have no association with various types of employment transition, except for land slide with a clear effect on positive transient farm (column 2) and a move from wage/salary sector to farming or household business (column 3). In respect to natural disasters in the year before previous year, drought is found to be associated with a move from wage to farming or household business (column 3 ) and transitory wage-household work status (column 5) and typhoon and land slide with positive transient farm (column 2).

\section{Empirical results and discussion}

We turn now to a multivariate analysis of the factors associated with being engaged in transitions in the rural area. The likelihood of engaging in each of these activities is modelled as a function of many of the factors already considered in the sub-section of 'Methods of analysis', and province fixed effects. The model is fixed effect so as to handle the problem of unobserved variables at individual level as well.

Table 5 shows results of fixed-effects multivariate probit models for the likelihood of transitions in the rural area, taking into account the individual characteristics in the initial year of 2008 (Model 1-ALT). Table 6 presents results of taking into account the changes in individual characteristics (Model 1A-ALT). Table 7 highlights the effects of the changes in household characteristics (Model 1B-ALT). Table 8 gives more evidence by taking into account the changes in commune characteristics (Model 1C-ALT). We use command gsem (generalized structural equation model) in Stata to estimate multivariate probit models (Huber, 2013; Huber, 2014).

The right-hand side variables can largely be regarded as exogenous. We include gender, material status, head of household, CPV membership, membership of Farmer Union, and education level as well, the relevance of them are strongly suggested by the results in Table 3 . In addition, age and the square of age are also in the model. Results of the set of regression models on the determinants of rural employment transitions are presented in Tables 5-8. The reported coefficients in Tables 5-8 are estimated of the effect of a marginal change in the corresponding regressor (or discrete change of a dummy variable from 0 to 1 ) on the probability of choosing one from five forms of employment transition. 
We firstly discuss the results of Model 1-ALT of individual characteristics in Table 5. Columns 1, 2, 3, 4, and 5 show the results for (1) the choice by an individual to be in agriculture during the survey period, (2) the choice to be employed in wage/salary sector, (3) the choice to move out of wage/salary sector, the choice to move out of household work to (4) farming and (5) to wage/salary sector, respectively.

Regarding the gender, ceteris paribus, the results show that males have a lower probability of 2.7 per cent to be persistent farming than females (column 1); males are more likely to move to wage/ salary sector than females (column 2 ) by 3.9 per cent (This is in line with most recent study by Sackey (2018)); males' probability to move out of wage/ salary sector is 2.0 per cent more than that of females (column 3); and males have a lower probability by 0.6 per cent to move from household work to farming than females (column 4).

With regard to the marital status of individual, ceteris paribus, the results indicate that married individuals have higher probability of 6.3 per cent to be persistent farming compared to the unmarried ones (column 1); married individuals are less likely to move from agriculture to wage/salary sector than the unmarried ones (column 2), about 5.8 per cent; married individuals are less likely to move from household work to farming (column 4) and from household work to wage/salary sector (column 5) than the unmarried ones by 6.3 per cent and 3.5 per cent, respectively.

Age is found to have an inversed U-shaped effect on choices to be persistent farming (column 1), to move from agriculture to wage/salary sector (column 2), to move out of wage/salary sector (column 3). This is in line with study of Liu and Liu (2016), who find that age is an important influence of off-farm employment decision. Sackey (2018) also finds an inversed U-shaped relationship between age and non-farm employment. In addition, ages are found to have a U-shaped effect on choices to move from household work to being farm (column 4), to move from household work to wage/salary sector (column 5).

With respect to the status of household head, the results show no significant effect of headed individual on all of possible employment transitions.

In relation to the Farmer Union's membership of individual, the results prove that householdhead individuals are 2.8 per cent more likely to be persistent farming, ceteris paribus. However, those household-head individuals are less likely to move out of wage/salary sector compared to other family members (column 3) or to move from household work to farming than other family members (column 4) by 3.7 per cent and 2.0 per cent respectively, ceteris paribus. Individual with CPV membership tends to leave farming (column 1) or be less likely to move from household work to farming (column 4), ceteris paribus, about 5.8 per cent and 1.2 per cent respectively.

In terms of educational levels, results in Table 5 suggest that individuals with primary, lower secondary school are more likely to be persistent in farming (column 1), ceteris paribus. In addition, individuals with lower and upper secondary school, and 'can read and write but never went to school' are more likely to move to wage/salary sector (column 2). This is in line with study of Liu and Liu (2016), and Sackey (2018), they find that education is an important influence of non-farm employment decision. Moreover, individuals with upper secondary school are more likely to move to out of wage/salary sector (column 3), ceteris paribus. Besides, individuals with lower and upper secondary school are less likely to move from household work to wage/salary sector (column 5), while holding all other variables in the model constant.

The results in Table 5 also reveal that individuals move out of wage/salary sector (column 3) when their households have higher income per capita level, and not to move to wage/salary sector (column 2), or not to move from household work to farming, ceteris paribus. Put it differently, income shocks may be associated with a move from agriculture to wage/salary sector or a move from household work to farming. This is in line with a most recent study in this field by Beck et al. (2018) (for the case of coffee farmers in the Central Highlands of Viet Nam).

Table 6 presents results of fixed-effects multivariate probit models for the likelihood of transitions in the rural area, taking into account the changes in individual characteristics (Model 1A-ALT). Results in Table 6 confirms similar findings for transition in the rural area as presented in Table 5. Table 6 further shows that, individuals with changes in marital status are more likely to move from agriculture to wage/salary sector (column 2). Accordingly, getting married is associated with about 4.2 percentage point higher probability that individuals move from agriculture to wage/salary sector. In addition, individuals with a completion of lower secondary school in the sample period are likely to have a probability 


\begin{tabular}{|c|c|c|c|c|c|}
\hline \multirow[t]{2}{*}{ Variable } & $\begin{array}{l}\text { Persistent } \\
\text { farming }\end{array}$ & $\begin{array}{l}\text { Positive transient farm } \\
\text { (From agriculture } \\
\text { to wage/salary sector) }\end{array}$ & $\begin{array}{l}\text { Out-of-wage } \\
\text { (From wage/salary } \\
\text { sector to farming } \\
\text { or HH business) }\end{array}$ & $\begin{array}{c}\text { Transitory farm-HH } \\
\text { work (From HH work } \\
\text { to farming) }\end{array}$ & $\begin{array}{c}\text { Transitory wage-HH } \\
\text { work (From HH work } \\
\text { to wage/salary sector) }\end{array}$ \\
\hline & (1) & (2) & (3) & (4) & (5) \\
\hline \multirow[t]{2}{*}{ Male (=1) } & $-0.0270^{*}$ & $0.0396^{* * *}$ & $0.0198 * *$ & $-0.0066 * * *$ & -0.0069 \\
\hline & $(0.0153)$ & $(0.0090)$ & $(0.0097)$ & $(0.0021)$ & $(0.0110)$ \\
\hline \multirow[t]{2}{*}{ Married (=1) } & $0.0534 * *$ & $-0.0582 * * *$ & -0.0114 & $-0.0634 * * *$ & $-0.0345 * *$ \\
\hline & $(0.0237)$ & $(0.0115)$ & $(0.0135)$ & $(0.0174)$ & $(0.0142)$ \\
\hline \multirow[t]{2}{*}{ Age (years) } & $0.0136 * * *$ & $0.0066^{* * *}$ & $0.0052 * * *$ & $-0.0012 * * *$ & $-0.0107 * * *$ \\
\hline & $(0.0025)$ & $(0.0013)$ & $(0.0017)$ & $(0.0003)$ & $(0.0014)$ \\
\hline \multirow[t]{2}{*}{ Age squared/100 } & $-0.0119 * * *$ & $-0.0089^{* * *}$ & $-0.0072 * * *$ & $0.0024 * * *$ & $0.0120^{* * *}$ \\
\hline & $(0.0026)$ & $(0.0017)$ & $(0.0022)$ & $(0.0005)$ & $(0.0015$ \\
\hline \multirow[t]{2}{*}{ Head of HH (=1) } & -0.0208 & -0.0144 & 0.0002 & & -0.0151 \\
\hline & $(0.0157)$ & $(0.0120)$ & $(0.0112)$ & & $(0.0185)$ \\
\hline \multirow[t]{2}{*}{ CPV membership $(=1)$} & $-0.0583^{*}$ & -0.0450 & 0.0151 & $-0.0116^{*}$ & 0.0508 \\
\hline & $(0.0345)$ & $(0.0355)$ & $(0.0186)$ & $(0.0060)$ & $(0.0366)$ \\
\hline \multirow[t]{2}{*}{ Member of Farm Union $(=1)$} & $0.0281 * *$ & -0.0166 & $-0.0369 * *$ & $-0.0197 * * *$ & -0.0361 \\
\hline & $(0.0127)$ & $(0.0153)$ & $(0.0160)$ & $(0.0041)$ & $(0.0277)$ \\
\hline \multirow[t]{2}{*}{ Completed primary $(=1)$} & $0.0376^{*}$ & 0.0101 & 0.0314 & -0.0035 & -0.0212 \\
\hline & $(0.0205)$ & $(0.0187)$ & $(0.0234)$ & $(0.0023)$ & $(0.0162)$ \\
\hline \multirow[t]{2}{*}{ Completed lower secondary $(=1)$} & $0.0568 * * *$ & $0.0278^{*}$ & 0.0271 & $-0.0171 * * *$ & $-0.0438 * * *$ \\
\hline & $(0.0220)$ & $(0.0167)$ & $(0.0215)$ & $(0.0052)$ & $(0.0164)$ \\
\hline \multirow[t]{2}{*}{ Completed upper secondary $(=1)$} & 0.0056 & $0.0483 * * *$ & $0.0605^{* * *}$ & $-0.0064 * *$ & $-0.0864 * * *$ \\
\hline & $(0.0269)$ & $(0.0178)$ & $(0.0219)$ & $(0.0030)$ & $(0.0231)$ \\
\hline \multirow[t]{2}{*}{ Can read and write but no school $(=1)$} & -0.0796 & $0.0731 * *$ & & $-0.0155^{* *}$ & -0.0139 \\
\hline & $(0.128)$ & $(0.0286)$ & & $(0.0072)$ & $(0.0319)$ \\
\hline \multirow[t]{2}{*}{ Net total income per capita in $2008(\log )$} & 0.0045 & $-0.0141 * * *$ & $0.0125^{* * *}$ & $-0.0028 * * *$ & -0.0011 \\
\hline & $(0.0053)$ & $(0.0034)$ & $(0.0040)$ & $(0.0008)$ & $(0.0052)$ \\
\hline Log Likelihood & & & -3271.6026 & & \\
\hline Observations & 2,698 & 2,698 & 2,698 & 2,698 & 2,698 \\
\hline
\end{tabular}

Note: HH: Household; Robust standard errors in parentheses; *** $\mathrm{p}<0.01, * * \mathrm{p}<0.05, * \mathrm{p}<0.1$

Method of estimation: fixed-effects multivariate probit models using gsem (generalized structural equation model) command in Stata (Huber, 2013; Huber, 2014)

Source: Author's estimation from VARHS 2008-2016

Table 5: Basic model of transitions in the rural area (marginal effect), 2008-16 (Model 1-ATL).

of higher 8.4 percentage point to be persistent in farming (column 1). Moreover, becoming a new member of Farmer Union in the sample period likely increases about 5.1 percentage point probability of being persistent farming (column 1).

Table 7 exposes results of fixed-effects multivariate probit models for the likelihood of transitions in the rural area, taking into account the changes in household characteristics (Model 1B-ALT). Results in Table 7 support similar findings for transition in the rural area as presented in Table 5. Table 7 also shows that individuals in household with an increase in the proportion of attaining primary school is likely to have a lower 2.7 percentage point probability to move to wage/salary sector (column 2), and individuals in household with an increase in the proportion of attaining lower secondary school is likely associated with a lower 4.03 percentage point probability to be in persistent farming (column 1), ceteris paribus.

With regard to change in demographic characteristics, individuals in household with an increase in the number of working-age 


\begin{tabular}{|c|c|c|c|c|c|}
\hline \multirow[t]{2}{*}{ Variable } & $\begin{array}{l}\text { Persistent } \\
\text { farming }\end{array}$ & $\begin{array}{l}\text { Positive transient farm } \\
\text { (From agriculture } \\
\text { to wage/salary sector) }\end{array}$ & $\begin{array}{c}\text { Out-of-wage } \\
\text { (From wage/salary } \\
\text { sector to farming } \\
\text { or HH business) }\end{array}$ & $\begin{array}{l}\text { Transitory farm-HH } \\
\text { work (From HH work } \\
\quad \text { to farming) }\end{array}$ & $\begin{array}{l}\text { Transitory wage-HH } \\
\text { work (From HH work } \\
\text { to wage/salary sector) }\end{array}$ \\
\hline & (1) & (2) & (3) & (4) & (5) \\
\hline \multirow[t]{2}{*}{ Male (=1) } & $-0.0336^{*}$ & $0.0388^{* * * *}$ & $0.0202 * *$ & -0.00001 & -0.0093 \\
\hline & $(0.0182)$ & $(0.0090)$ & $(0.0098)$ & $(0.00001)$ & $(0.0107)$ \\
\hline \multirow{2}{*}{ Married (=1) } & $0.0391 *$ & $-0.0525 * * *$ & -0.0082 & -0.00001 & $-0.0387 * * *$ \\
\hline & $(0.0229)$ & $(0.0118)$ & $(0.0139)$ & $(0.00001)$ & $(0.0145)$ \\
\hline \multirow[t]{2}{*}{ Age (years) } & $0.0149 * * *$ & $0.0064 * * *$ & $0.0051^{* * *}$ & -0.00001 & $-0.0111 * * *$ \\
\hline & $(0.0023)$ & $(0.0013)$ & $(0.0017)$ & $(0.00001)$ & $(0.0014)$ \\
\hline \multirow[t]{2}{*}{ Age squared/100 } & $-0.0123 * * *$ & $-0.00850 * * *$ & $-0.00707 * * *$ & -0.00001 & $0.0126^{* * *}$ \\
\hline & $(0.0029)$ & $(0.0017)$ & $(0.0022)$ & $(0.00001)$ & $(0.0015)$ \\
\hline \multirow[t]{2}{*}{ Head of HH (=1) } & -0.0284 & -0.0142 & 0.0005 & & -0.0134 \\
\hline & $(0.0193)$ & $(0.0120)$ & $(0.0114)$ & & $(0.0183)$ \\
\hline \multirow[t]{2}{*}{ CPV membership (=1) } & $-0.0884 * *$ & -0.0421 & 0.0154 & 0.00003 & 0.0427 \\
\hline & $(0.0447)$ & $(0.0350)$ & $(0.0189)$ & $(0.00002)$ & $(0.0355)$ \\
\hline \multirow[t]{2}{*}{ Member of Farm Union $(=1)$} & $0.0326^{*}$ & -0.0155 & $-0.0370 * *$ & 0.00001 & -0.0367 \\
\hline & $(0.0197)$ & $(0.0153)$ & $(0.0163)$ & $(0.00001)$ & $(0.0273)$ \\
\hline \multirow[t]{2}{*}{ Completed primary $(=1)$} & $0.0525^{\text {** }}$ & 0.0105 & 0.0364 & -0.0001 & -0.0160 \\
\hline & $(0.0246)$ & $(0.0191)$ & $(0.0236)$ & $(0.0001)$ & $(0.0162)$ \\
\hline Completed lower secondary $(=1)$ & $\begin{array}{c}0.0765 * * * \\
(0.0250)\end{array}$ & $\begin{array}{c}0.0274 \\
(0.0173)\end{array}$ & $\begin{array}{c}0.0329 \\
(0.0217)\end{array}$ & $\begin{array}{c}-0.0001 * \\
(0.00001)\end{array}$ & $\begin{array}{c}-0.0371 * * \\
(0.0163)\end{array}$ \\
\hline Completed upper secondary $(=1)$ & $\begin{array}{c}0.0112 \\
(0.0313)\end{array}$ & $\begin{array}{c}0.0465^{* *} \\
(0.0184)\end{array}$ & $\begin{array}{c}0.0670 * * * \\
(0.0224)\end{array}$ & $\begin{array}{c}-0.00001 \\
0.0001)\end{array}$ & $\begin{array}{c}-0.0747 * * * \\
(0.0229)\end{array}$ \\
\hline Can read and write but no school $(=1)$ & $\begin{array}{c}-0.0989^{*} \\
(0.0585)\end{array}$ & $\begin{array}{c}0.0748 * * * \\
(0.0286)\end{array}$ & & $\begin{array}{l}-0.0001 * \\
(0.0001)\end{array}$ & $\begin{array}{l}-0.0093 \\
(0.0312)\end{array}$ \\
\hline Net total income per capita in $2008(\log )$ & $\begin{array}{c}0.0107 \\
(0.0104)\end{array}$ & $\begin{array}{c}-0.0140 * * * \\
(0.0034)\end{array}$ & $\begin{array}{c}0.0126^{* * * *} \\
(0.0041)\end{array}$ & $\begin{array}{c}-0.00002 \\
(0.00002)\end{array}$ & $\begin{array}{l}-0.0019 \\
(0.0050)\end{array}$ \\
\hline \multicolumn{6}{|c|}{ Changes of individual characteristics between 2016 and 2008, from No (in 2008) to Yes (in 2016) (dummy) } \\
\hline \multirow[t]{2}{*}{ Married } & 0.0461 & $0.0419^{* * *}$ & 0.0056 & 0.00003 & -0.0236 \\
\hline & $(0.0623)$ & $(0.0151)$ & $(0.0203)$ & $(0.00002)$ & $(0.0251)$ \\
\hline \multirow[t]{2}{*}{ Completed lower secondary } & $0.0840^{* *}$ & -0.0250 & & -0.00005 & 0.0026 \\
\hline & $(0.0364)$ & $(0.0365)$ & & $(0.00004)$ & $(0.0269)$ \\
\hline \multirow[t]{2}{*}{ Completed upper secondary } & -0.0219 & 0.0137 & 0.0042 & -0.00007 & 0.0151 \\
\hline & $(0.0342)$ & $(0.0177)$ & $(0.0187)$ & $(0.00005)$ & $(0.0170)$ \\
\hline \multirow[t]{2}{*}{ Farmer Union member } & $0.0512 *$ & 0.0025 & -0.0033 & & 0.0070 \\
\hline & $(0.0284)$ & $(0.0204)$ & $(0.0198)$ & & $(0.0318)$ \\
\hline Log Likelihood & & & -3424.7907 & & \\
\hline Observations & 2,698 & 2,698 & 2,698 & 2,698 & 2,698 \\
\hline
\end{tabular}

Note: HH: Household; Robust standard errors in parentheses; *** $\mathrm{p}<0.01, * * \mathrm{p}<0.05, * \mathrm{p}<0.1$

Method of estimation: fixed-effects multivariate probit models using gsem (generalized structural equation model) command in Stata (Huber, 2013; Huber, 2014)

Source: Author's estimation from VARHS 2008-2016

Table 6: Extension model of transitions in the rural area (marginal effect): changes of individual characteristics in 2008-16 (Model 1A-ALT).

members is less likely to move from household work to farming (column 4). In addition, individuals in household with higher ratio of children under 16 and elderly members is more likely to move from agriculture to wage/salary sector (column 5) and to move from household work to farming (column 4), with an association of higher probability of about 1.8 percentage. Moreover, individuals in household with a change in household head is less likely to move from household work to farming (column 4), with an association of lower probability of about 0.3 percentage.

With respect to changes in social capital, individuals in household with $\mathrm{CPV}$ members is more likely to move out of wage/salary sector to household business or farming (column 3). An increase in CPV member of household 
is associated with a higher probability of 4.5 percentage, ceteris paribus. In addition, an increase in supports from relatives is associated with a higher 0.2 percentage point probability of moving from household work to farming.

Regarding changes in land, individuals in household with increase land is less likely to move out of wage/salary sector to household business or farming (column 3) or to move from household work to farming (column 4). In addition, individuals in household with land loss is more likely to move from household work to wage/salary sector (column 5) or to become persistent farming (column 1).

\begin{tabular}{|c|c|c|c|c|c|}
\hline \multirow[t]{2}{*}{ Variable } & $\begin{array}{l}\text { Persistent } \\
\text { farming }\end{array}$ & $\begin{array}{l}\text { Positive transient farm } \\
\text { (From agriculture } \\
\text { to wage/salary sector) }\end{array}$ & $\begin{array}{l}\text { Out-of-wage } \\
\text { (From wage/salary } \\
\text { sector to farming } \\
\text { or HH business) }\end{array}$ & $\begin{array}{c}\text { Transitory farm-HH } \\
\text { work (From HH work } \\
\text { to farming) }\end{array}$ & $\begin{array}{l}\text { Transitory wage-HH } \\
\text { work (From HH work } \\
\text { to wage/salary sector) }\end{array}$ \\
\hline & (1) & (2) & (3) & (4) & (5) \\
\hline \multirow[t]{2}{*}{ Male (=1) } & $-0.0426^{* *}$ & $0.0407 * * *$ & $0.0182 *$ & $-0.0017 * * *$ & -0.0099 \\
\hline & $(0.0177)$ & $(0.0089)$ & $(0.0097)$ & $(0.0005)$ & $(0.0112)$ \\
\hline \multirow[t]{2}{*}{ Married (=1) } & $0.0520 * *$ & $-0.0550 * * *$ & -0.0085 & $-0.0054 * * *$ & $-0.0295^{* *}$ \\
\hline & $(0.0212)$ & $(0.0119)$ & $(0.0129)$ & $(0.0013)$ & $(0.0150)$ \\
\hline \multirow[t]{2}{*}{ Age (years) } & $0.0122 * * *$ & $0.0057 * * *$ & $0.0045^{* * *}$ & $-0.0005 * * *$ & $-0.0119 * * *$ \\
\hline & $(0.0023)$ & $(0.0013)$ & $(0.0017)$ & $(0.0002)$ & $(0.0015)$ \\
\hline \multirow[t]{2}{*}{ Age squared/100 } & $-0.0101 * * *$ & $-0.0078 * * *$ & $-0.0066 * * *$ & $0.0007^{* * *}$ & $0.0134 * * *$ \\
\hline & $(0.0025)$ & $(0.0017)$ & $(0.0021)$ & $(0.0002)$ & $(0.0017)$ \\
\hline \multirow[t]{2}{*}{ Head of HH (=1) } & -0.0169 & -0.0143 & 0.0043 & & -0.0114 \\
\hline & $(0.0192)$ & $(0.0124)$ & $(0.0116)$ & & $(0.0187)$ \\
\hline \multirow[t]{2}{*}{ CPV membership $(=1)$} & $-0.0798^{*}$ & -0.0470 & 0.0156 & $0.0027 * * *$ & 0.0483 \\
\hline & $(0.0449)$ & $(0.0354)$ & $(0.0188)$ & $(0.0007)$ & $(0.0370)$ \\
\hline Member of Farm Union (=1) & $\begin{array}{c}0.0313 \\
(0.0199)\end{array}$ & $\begin{array}{l}-0.0199 \\
(0.0148)\end{array}$ & $\begin{array}{c}-0.0362 * * \\
(0.0154)\end{array}$ & $\begin{array}{c}0.0001 \\
(0.0002)\end{array}$ & $\begin{array}{l}-0.0362 \\
(0.0267)\end{array}$ \\
\hline Completed primary $(=1)$ & $\begin{array}{c}0.0388 \\
(0.0244)\end{array}$ & $\begin{array}{c}0.0086 \\
(0.0187)\end{array}$ & $\begin{array}{l}0.0424 * \\
(0.0217)\end{array}$ & $\begin{array}{c}-0.0031 * * * \\
(0.0009)\end{array}$ & $\begin{array}{l}-0.0217 \\
(0.0166)\end{array}$ \\
\hline Completed lower secondary $(=1)$ & $\begin{array}{c}0.0599 * * \\
(0.0247)\end{array}$ & $\begin{array}{c}0.0234 \\
(0.0170)\end{array}$ & $\begin{array}{l}0.0368^{*} \\
(0.0201)\end{array}$ & $\begin{array}{c}-0.0020^{* * * *} \\
(0.0006)\end{array}$ & $\begin{array}{c}-0.0390^{* *} \\
(0.0168)\end{array}$ \\
\hline Completed upper secondary $(=1)$ & $\begin{array}{l}-0.0065 \\
(0.0311)\end{array}$ & $\begin{array}{c}0.0389 * * \\
(0.0177)\end{array}$ & $\begin{array}{c}0.0670 * * * \\
(0.0210)\end{array}$ & $\begin{array}{c}0.0005^{* *} \\
(0.0003)\end{array}$ & $\begin{array}{c}-0.0806 * * * \\
(0.0237)\end{array}$ \\
\hline Can read and write but no school $(=1)$ & $\begin{array}{l}-0.100^{*} \\
(0.0591)\end{array}$ & $\begin{array}{c}0.0793 * * * \\
(0.0276)\end{array}$ & & $\begin{array}{c}-0.0109^{* * * *} \\
(0.0029)\end{array}$ & $\begin{array}{l}-0.0162 \\
(0.0320)\end{array}$ \\
\hline Net total income per capita in $2008(\log )$ & $\begin{array}{c}0.0062 \\
(0.0078)\end{array}$ & $\begin{array}{c}-0.0123 * * * \\
(0.0032)\end{array}$ & $\begin{array}{c}0.0115^{* *} \\
(0.0046)\end{array}$ & $\begin{array}{c}-0.0011 * * * \\
(0.0003)\end{array}$ & $\begin{array}{l}-0.0028 \\
(0.0049)\end{array}$ \\
\hline \multicolumn{6}{|c|}{ Changes of household characteristics between 2016 and 2008, from No (in 2008) to Yes (in 2016) (dummy) } \\
\hline \multirow[t]{2}{*}{ Completed primary } & -0.0153 & $-0.0273 * *$ & 0.0125 & 0.0002 & 0.0067 \\
\hline & $(0.0160)$ & $(0.0107)$ & $(0.0087)$ & $(0.0002)$ & $(0.0119)$ \\
\hline Completed upper secondary & $\begin{array}{c}-0.0403 * * * \\
(0.0144)\end{array}$ & $\begin{array}{c}0.0063 \\
(0.0080)\end{array}$ & $\begin{array}{c}-0.0024 \\
(0.0078)\end{array}$ & $\begin{array}{c}-0.00003 \\
(0.0001)\end{array}$ & $\begin{array}{l}-0.0076 \\
(0.0113)\end{array}$ \\
\hline \multirow[t]{2}{*}{ Household size } & 0.0198 & -0.0117 & 0.0143 & 0.000185 & 0.0076 \\
\hline & $(0.0184)$ & $(0.0104)$ & $(0.0094)$ & $(0.0001)$ & $(0.0130)$ \\
\hline \multirow[t]{2}{*}{ Mean of working ages } & 0.0111 & 0.0017 & -0.0102 & -0.0001 & -0.0135 \\
\hline & $(0.0146)$ & $(0.0082)$ & $(0.0081)$ & $(0.0001)$ & $(0.0100)$ \\
\hline Number of working-age members & $\begin{array}{l}-0.0277 \\
(0.0175)\end{array}$ & $\begin{array}{l}-0.0124 \\
(0.0093)\end{array}$ & $\begin{array}{l}-0.0161 \\
(0.0099)\end{array}$ & $\begin{array}{c}-0.0005^{*} \\
(0.0002)\end{array}$ & $\begin{array}{l}-0.0049 \\
(0.0123)\end{array}$ \\
\hline The ratio of children under 16 & $\begin{array}{c}-0.0218 \\
(0.0179)\end{array}$ & $\begin{array}{l}0.0182 * \\
(0.0101)\end{array}$ & $\begin{array}{c}0.0118 \\
(0.0096)\end{array}$ & $\begin{array}{c}0.0018^{* * *} \\
(0.0005)\end{array}$ & $\begin{array}{l}-0.0249 \\
(0.0161)\end{array}$ \\
\hline
\end{tabular}

Note: HH: Household; Robust standard errors in parentheses; $* * * \mathrm{p}<0.01,{ }^{* *} \mathrm{p}<0.05,{ }^{*} \mathrm{p}<0.1$

Method of estimation: fixed-effects multivariate probit models using gsem (generalized structural equation model) command in Stata (Huber, 2013; Huber, 2014)

Source: Author's estimation from VARHS 2008-2016

Table 7: Extension model of transitions in the rural area (marginal effect): changes of household characteristics in 2008-16 (Model 1B-ALT) (to be continued). 


\begin{tabular}{|c|c|c|c|c|c|}
\hline \multirow[t]{2}{*}{ Variable } & $\begin{array}{l}\text { Persistent } \\
\text { farming }\end{array}$ & $\begin{array}{l}\text { Positive transient farm } \\
\text { (From agriculture } \\
\text { to wage/salary sector) }\end{array}$ & $\begin{array}{l}\text { Out-of-wage } \\
\text { (From wage/salary } \\
\text { sector to farming } \\
\text { or HH business) }\end{array}$ & $\begin{array}{l}\text { Transitory farm-HH } \\
\text { work (From } \mathrm{HH} \text { work } \\
\text { to farming) }\end{array}$ & $\begin{array}{l}\text { Transitory wage-HH } \\
\text { work (From HH work } \\
\text { to wage/salary sector) }\end{array}$ \\
\hline & (1) & (2) & (3) & (4) & (5) \\
\hline $\begin{array}{l}\text { CPV member(s) (Counting the HH head) } \\
\text { of } \mathrm{HH}\end{array}$ & $\begin{array}{c}0.0176 \\
(0.0579)\end{array}$ & $\begin{array}{l}-0.0274 \\
(0.0401)\end{array}$ & $\begin{array}{l}0.0445^{*} \\
(0.0258)\end{array}$ & & $\begin{array}{l}-0.0538 \\
(0.0519)\end{array}$ \\
\hline \multirow[t]{2}{*}{ Land increased } & 0.0252 & 0.0182 & $-0.0225^{*}$ & $-0.0010^{* * *}$ & 0.0155 \\
\hline & $(0.0197)$ & $(0.0121)$ & $(0.0134)$ & $(0.0003)$ & $(0.0153)$ \\
\hline \multirow[t]{2}{*}{ Land loss } & $0.0298 *$ & 0.0123 & -0.00370 & & $0.0287 * *$ \\
\hline & $(0.0181)$ & $(0.0098)$ & $(0.0099)$ & & $(0.0126)$ \\
\hline \multirow[t]{2}{*}{ Income increased } & 0.0369 & $0.0345^{*}$ & 0.0062 & $-0.0036^{* * *}$ & -0.0217 \\
\hline & $(0.0243)$ & $(0.0190)$ & $(0.0127)$ & $(0.0009)$ & $(0.0152)$ \\
\hline Political network member & $\begin{array}{l}-0.0226 \\
(0.0308)\end{array}$ & $\begin{array}{l}-0.0200 \\
(0.0185)\end{array}$ & $\begin{array}{l}-0.0238 \\
(0.0214)\end{array}$ & & $\begin{array}{c}0.0321 \\
(0.0207)\end{array}$ \\
\hline \multirow[t]{2}{*}{ Supports from relatives } & -0.0027 & -0.0089 & 0.00472 & $0.0002 * *$ & -0.0051 \\
\hline & $(0.0171)$ & $(0.0115)$ & $(0.0098)$ & $(0.0001)$ & $(0.0157)$ \\
\hline \multirow[t]{2}{*}{ Natural shock } & 0.0134 & -0.0063 & -0.0309 & $-0.0016^{* * *}$ & -0.0079 \\
\hline & $(0.0460)$ & $(0.0238)$ & $(0.0279)$ & $(0.0005)$ & $(0.0263)$ \\
\hline \multirow[t]{2}{*}{ Pesticide shock } & -0.0109 & -0.0363 & & $0.0012 * * *$ & -0.0016 \\
\hline & $(0.0576)$ & $(0.0330)$ & & $(0.0004)$ & $(0.0364)$ \\
\hline \multirow[t]{2}{*}{ Head of $\mathrm{HH}$} & & 0.0331 & 0.0004 & $-0.0031^{* * *}$ & 0.0335 \\
\hline & & $(0.0328)$ & $(0.0413)$ & $(0.0010)$ & $(0.0321)$ \\
\hline Log Likelihood & & & -3225.8514 & & \\
\hline Observations & 2,698 & 2,698 & 2,698 & 2,698 & 2,698 \\
\hline
\end{tabular}

Note: HH: Household; Robust standard errors in parentheses; $* * * \mathrm{p}<0.01, * * \mathrm{p}<0.05, * \mathrm{p}<0.1$

Method of estimation: fixed-effects multivariate probit models using gsem (generalized structural equation model) command in Stata (Huber, 2013; Huber, 2014)

Source: Author's estimation from VARHS 2008-2016

Table 7: Extension model of transitions in the rural area (marginal effect): changes of household characteristics in 2008-16 (Model 1B-ALT) (continuation).

With regard to income per capita, individuals in household with an increase in per capita income is more likely to move from agriculture to wage/ salary sector (column 2) with an association of higher probability of about 3.5 percentage and less likely to move from household work to farming (column 4) with an association of lower probability of about 0.4 percentage. Moreover, individuals in household with a change in household head is less likely to move from household work to farming (column 4), with an association of lower probability of about 0.3 percentage.

Regarding to shocks, individuals in household with natural shock is less likely to move from household work to farming (column 4) with an association of lower probability of about 0.2 percentage. Moreover, individuals in household with pesticide shock is more likely to move from household work to farming (column 4), with an association of higher probability of about 0.1 percentage.

Table 8 displays results of fixed-effects multivariate probit models for the likelihood of transitions in the rural area, taking into account the changes in commune characteristics (Model 1C-ALT). Results in Table 8 affirm similar findings for transition from agriculture as presented in Table 5. Table 8 also shows that individuals in commune with changes in natural shocks such as drought is less likely to move out of wage/salary sector to farming or household business (column 3), less likely to move from household work to farming (column 4). In addition, individuals in commune with changes in natural shocks such as typhoon is less likely to move from agriculture to wage/ salary sector (column 2). However, individuals in commune with changes in natural shocks such as land slide occurred in the year before last year is also more likely to move to wage/salary sector from farming (column 2). Individuals in commune with changes in natural shocks such as land slide in the last year is more likely to move from household work to farming (column 4), whereas individuals in commune with changes in natural shocks such as land slide occurred in the year before last year is less likely to move from household work to farming (column 4). 


\begin{tabular}{|c|c|c|c|c|c|}
\hline \multirow[t]{2}{*}{ Variable } & $\begin{array}{l}\text { Persistent } \\
\text { farming }\end{array}$ & $\begin{array}{l}\text { Positive transient farm } \\
\text { (From agriculture } \\
\text { to wage/salary sector) }\end{array}$ & $\begin{array}{l}\text { Out-of-wage } \\
\text { (From wage/salary } \\
\text { sector to farming } \\
\text { or HH business) }\end{array}$ & $\begin{array}{l}\text { Transitory farm-HH } \\
\text { work (From HH work } \\
\text { to farming) }\end{array}$ & $\begin{array}{l}\text { Transitory wage-HH } \\
\text { work (From HH work } \\
\text { to wage/salary sector) }\end{array}$ \\
\hline & (1) & (2) & (3) & (4) & (5) \\
\hline \multirow[t]{2}{*}{ Male $(=1)$} & $-0.0336^{*}$ & $0.0401 * * *$ & $0.0203 * *$ & 0.00003 & -0.0097 \\
\hline & $(0.0189)$ & $(0.0088)$ & $(0.0096)$ & $(0.00002)$ & $(0.0109)$ \\
\hline \multirow[t]{2}{*}{ Married (=1) } & $0.0386^{*}$ & $-0.0561 * * *$ & -0.0091 & $0.00007^{*}$ & $-0.0418^{* * *}$ \\
\hline & $(0.0231)$ & $(0.0116)$ & $(0.0133)$ & $(0.00004)$ & $(0.0151)$ \\
\hline \multirow[t]{2}{*}{ Age (years) } & $0.0161 * * *$ & $0.0063 * * *$ & $0.0050 * * *$ & $-0.0001 * * *$ & $-0.0109 * * *$ \\
\hline & $(0.0027)$ & $(0.0013)$ & $(0.00168)$ & $(0.00004)$ & $(0.0014)$ \\
\hline \multirow[t]{2}{*}{ Age squared/100 } & $-0.0135 * * *$ & $-0.0085 * * *$ & $-0.0070 * * *$ & $0.0001 * * *$ & $0.0124 * * *$ \\
\hline & $(0.0030)$ & $(0.0016)$ & $(0.0021)$ & $(0.00004)$ & $(0.0015)$ \\
\hline \multirow[t]{2}{*}{ Head of HH (=1) } & -0.0263 & -0.0154 & 0.0010 & & -0.0131 \\
\hline & $(0.0193)$ & $(0.0119)$ & $(0.0112)$ & & $(0.0187)$ \\
\hline CPV membership $(=1)$ & $\begin{array}{c}-0.0932 * * \\
(0.0452)\end{array}$ & $\begin{array}{l}-0.0465 \\
(0.0357)\end{array}$ & $\begin{array}{c}0.0127 \\
(0.0185)\end{array}$ & $\begin{array}{c}0.0006 * * * \\
(0.0002)\end{array}$ & $\begin{array}{c}0.0437 \\
(0.0367)\end{array}$ \\
\hline Member of Farm Union $(=1)$ & $\begin{array}{c}0.0295 \\
(0.0201)\end{array}$ & $\begin{array}{l}-0.0180 \\
(0.0151)\end{array}$ & $\begin{array}{c}-0.0370^{* *} \\
(0.0158)\end{array}$ & $\begin{array}{l}-0.0001^{* *} \\
(0.00005)\end{array}$ & $\begin{array}{l}-0.0365 \\
(0.0278)\end{array}$ \\
\hline Completed primary $(=1)$ & $\begin{array}{c}0.0556^{* *} \\
(0.0249)\end{array}$ & $\begin{array}{c}0.0133 \\
(0.0193)\end{array}$ & $\begin{array}{c}0.0371 \\
(0.0235)\end{array}$ & $\begin{array}{c}-0.0007 * * * \\
(0.0002)\end{array}$ & $\begin{array}{l}-0.0131 \\
(0.0164)\end{array}$ \\
\hline Completed lower secondary $(=1)$ & $\begin{array}{c}0.0737 * * * \\
(0.0255)\end{array}$ & $\begin{array}{l}0.0317 * \\
(0.0175)\end{array}$ & $\begin{array}{c}0.0326 \\
(0.0217)\end{array}$ & $\begin{array}{c}-0.0005^{* * * *} \\
(0.0001)\end{array}$ & $\begin{array}{c}-0.0379^{* *} \\
(0.0165)\end{array}$ \\
\hline Completed upper secondary $(=1)$ & $\begin{array}{c}0.0115 \\
(0.0323)\end{array}$ & $\begin{array}{c}0.0518 * * * \\
(0.0185)\end{array}$ & $\begin{array}{c}0.0651^{* * *} \\
(0.0222)\end{array}$ & $\begin{array}{c}0.0003 * * * \\
(0.0001)\end{array}$ & $\begin{array}{c}-0.0789 * * * \\
(0.0233)\end{array}$ \\
\hline Can read and write but no school $(=1)$ & $\begin{array}{l}-0.0920 \\
(0.0595)\end{array}$ & $\begin{array}{c}0.0808^{* * *} \\
(0.0287)\end{array}$ & & $\begin{array}{c}-0.0003 * * \\
(0.0001)\end{array}$ & $\begin{array}{l}-0.0086 \\
(0.0317)\end{array}$ \\
\hline Net total income per capita in $2008(\log )$ & $\begin{array}{c}0.0109 \\
(0.0103)\end{array}$ & $\begin{array}{c}-0.0139 * * * \\
(0.0035)\end{array}$ & $\begin{array}{c}0.0124 * * * \\
(0.0040)\end{array}$ & $\begin{array}{c}-0.0001 * * * \\
(0.0001)\end{array}$ & $\begin{array}{c}-0.0021 \\
(0.0050)\end{array}$ \\
\hline \multicolumn{6}{|c|}{ Changes of local climate condition at the commune level between 2016 and 2008, from No (in 2008) to Yes (in 2016) (dummy) } \\
\hline \multirow[t]{2}{*}{ Land slide, $\mathrm{t}-1$} & 0.0143 & 0.0123 & -0.0413 & $0.0001^{*}$ & 0.0243 \\
\hline & $(0.0368)$ & $(0.0162)$ & $(0.0324)$ & $(0.00005)$ & $(0.0206)$ \\
\hline \multirow[t]{2}{*}{ Drought, $\mathrm{t}-2$} & 0.0224 & -0.0182 & $-0.0414^{* * *}$ & $-0.0003^{* * *}$ & 0.0107 \\
\hline & $(0.0184)$ & $(0.0120)$ & $(0.0129)$ & $(0.00008)$ & $(0.0119)$ \\
\hline \multirow[t]{2}{*}{ Typhoon, t-2 } & 0.0177 & $-0.0312 * *$ & -0.0125 & -0.00004 & -0.0186 \\
\hline & $(0.0210)$ & $(0.0148)$ & $(0.0130)$ & $(0.00003)$ & $(0.0157)$ \\
\hline \multirow[t]{2}{*}{ Land slide, t-2 } & -0.0266 & $0.0295^{*}$ & 0.00290 & $-0.0004 * * *$ & -0.00143 \\
\hline & $(0.0338)$ & $(0.0154)$ & $(0.0219)$ & $(0.0001)$ & $(0.0214)$ \\
\hline Log Likelihood & & & -3249.3025 & & \\
\hline Observations & 2,698 & 2,698 & 2,698 & 2,698 & 2,698 \\
\hline
\end{tabular}

Note: HH: Household; Robust standard errors in parentheses; *** $\mathrm{p}<0.01, * * \mathrm{p}<0.05, * \mathrm{p}<0.1$

Method of estimation: fixed-effects multivariate probit models using gsem (generalized structural equation model) command in Stata (Huber, 2013; Huber, 2014)

Source: Author's estimation from VARHS 2008-2016

Table 8: Extension model of transitions in the rural area (marginal effect): changes of commune characteristics in 2008-16 (Model 1C-ALT).

\section{Conclusion}

This paper is the first attempt to analyse the employment transitions in the rural area of Viet Nam by using a unique individuallevel dataset. Starting from the VARHS dataset with the five waves from 12 provinces of rural Viet Nam, compilation is further processed by using the individual identification in combination with the information on age and gender, besides the common use of household identification, and result in 2,698 individual-level observations in two years: 2008 and 2016. We find that initial individual-level human capital such as gender, marital status, age, and education attainment, and social capital such as member of socialpolitical organization are important factors affecting employment transition status in the rural area. In addition, changes in individual, household characteristics and local climate conditions 
at commune level are very important to affect various types of employment transition.

Specifically, in regard to changes in individual characteristics, individuals with changes in marital status are more likely to move from agriculture to wage/salary sector. In addition, individuals with completion of lower secondary school in the sample period are more likely to be persistent in farming. Besides, being a member of Farmer Union likely increases the probability of being persistent farming.

With respect to changes in household level, individuals in household with changes in the proportion of attaining primary school are less likely to move from agriculture to wage/salary sector, and individuals in household with changes in the proportion of attaining lower secondary school are less likely to be in persistent farming. In addition, with regard to change in demographic characteristics, individuals in household with an increase in the number of working-age members are less likely to move from household work to farming. Moreover, individuals in household with higher ratio of children under 16 and elderly members are more likely to move from agriculture to wage/salary sector and to move from household work to farming. Furthermore, individuals in household with a change in household head is less likely to move from household work to farming.

Besides, with respect to changes in social capital, individuals in household with CPV members are more likely to move out of wage/salary sector to farming or household business. In addition, individuals in household with supports from relatives are more likely to move from household work to farming.

On top of that, regarding changes in land, individuals in household with increased land are less likely to move out of wage/salary sector to household business or farming or to move from household work to farming. In addition, individuals in household with land loss are more likely to choose to move from household work to wage/salary sector or to become persistent farming.

With regard to income per capita, individuals in household with an increase in per capita income is more likely to move from agriculture to wage/ salary sector and less likely to move from household work to farming. Moreover, individuals in household with a change in household head is less likely to move from household work to farming.
Regarding to shocks, individuals in household with natural shock is less likely to move from household work to farming. Moreover, individuals in household with pesticide shock is more likely to move from household work to farming.

Regarding changes in local climate conditions at the commune level, individuals in commune with changes in natural shocks such as drought is less likely to move out of wage/salary sector to farming or household business, less likely to move from household work to farming. In addition, individuals in commune with changes in natural shocks such as typhoon is less likely to move from agriculture to wage/salary sector. However, individuals in commune with changes in natural shocks such as land slide occurred in the year before last year is also more likely to move to wage/salary sector from farming. Individuals in commune with changes in natural shocks such as land slide in the last year is more likely to move from household work to farming, whereas individuals in commune with changes in natural shocks such as land slide occurred in the year before last year is less likely to move from household work to farming.

Results have implications for development policy for rural transition in developing countries, highlighting the importance of the positive aspects of changes in individual-, household-, and commune-levels for rural transformation. Promotion of education attainment is necessary at both individual- and household-level to spur the transition out of farming. Broadened policy mechanisms which support and encourage non-farm employment at the household level are also needed. Likewise, development initiatives that focus on increasing the human and social assets of the individual farmers and farming households are more likely to be successful in supporting livelihood diversification and reducing vulnerability.

\section{Acknowledgments}

The working version of this article was published as Ngo (2018). We would like to thank UNUWIDER as the original commissioning institute. The copyright of the working paper has been transferred to Quang-Thanh Ngo and co-authors. The authors are grateful to Finn Tarp and Saurabh Singhal for their kind support and valuable comments. 
Corresponding authors

Quang-Thanh Ngo, Ph.D.

University of Economics and Law (UEL), Vietnam National University Ho Chi Minh City (VNU-HCM)

Quarter 3, Linh Xuan Ward, Thu Duc District, Ho Chi Minh City, Vietnam

Phone: (84)816891111,E-mail: thanhnq@uel.edu.vn

ORCID: 0000-0001-8357-1957

\section{References}

[1] Banerjee, B. (1983) "The role of the informal sector in the migration process: A test of probabilistic migration models and labour market segmentation for India", Oxford Economic Papers, Vol. 35, No. 3, pp. 399-422. ISSN 0030-7653. DOI 10.1093/oxfordjournals.oep.a041604.

[2] Barrett, C. B., Reardon, T. and Webb, P. (2001) "Nonfarm income diversification and household livelihood strategies in rural Africa: concepts, dynamics, and policy implications", Food Policy, Vol. 26, No. 4, pp. 315-331. ISSN 0306-9192. DOI 10.1016/S0306-9192(01)00014-8.

[3] Barrett, S. (2014) "Subnational Climate Justice? Adaptation Finance Distribution and Climate Vulnerability", World Development, Vol. 58, pp. 130-142. ISSN 0305-750X. DOI 10.1016/j.worlddev.2014.01.014.

[4] Beck, U., Singhal, S. and Tarp, F. (2018) "Commodity prices and intra-household labor allocation", American Journal of Agricultural Economics, Vol. 101, No. 2, E-ISSN 1467-8276, ISSN 0002-9092. DOI 10.1093/ajae/aay082.

[5] Berdegué, J. A., Ramírez, E., Reardon, T. and Escobar, G. (2001) "Rural nonfarm employment and incomes in Chile", World Development, Vol. 29, No. 3, pp. 411-425. ISSN 0305-750X. DOI 10.1016/S0305-750X(00)00102-9.

[6] Bezemer, D. and Davis, J. (2002) "The rural non-agricultural economy in transition countries: findings from Armenia", Natural Resource Institute Working Paper, NRI Report, 2678. [Online]. Available: $\quad$ https://gala.gre.ac.uk/id/eprint/11651/1/11651_Davis_The\%20rural\%20non\%20 agricultural\%20economy\%20in\%20transition\%20(working\%20paper)\%를.p2002.pdf. [Accessed: 31 Jan. 2019].

[7] CIEM, DOE, ILSSA, and IPSARD (2009) "Vietnam Access to Resources Household Survey: Characteristics of the Vietnamese Rural Economy (2008 Survey)", Hanoi: Statistical Publishing House.

[8] Coppard, D. (2001) "The rural non-farm economy in India: A review of the literature", Natural Resource Institute Working Paper, NRI Report, 2662. [Online]. Available: https://gala.gre.ac.uk/id/ eprint/11644/1/11644_Coppard_The\%20rural\%20non\%20farm\%20economy\%20in\%20India $\% 20$ (working\%20paper)\%202001.pdf [Accessed: 31 Jan. 2019].

[9] Davis, J. R. (2003) "The rural-non-farm economy, livelihoods and their diversification: Issues and options", Natural Resource Institute Working Paper, NRI Report, 2753. ISSN 1556-5068. DOI 10.2139/ssrn.691821.

[10] Deininger, K. and Olinto, P. (2001) "Rural nonfarm employment and income diversification in Colombia", World Development, Vol. 29, No. 3, pp. 455-465. ISSN 0305-750X. DOI 10.1016/S0305-750X(00)00106-6.

[11] Doss, C., McPeak, J. and Barrett, C. B. (2008) "Interpersonal, Intertemporal and Spatial Variation in Risk Perceptions: Evidence from East Africa", World Development, Vol. 36, No. 8, pp. 1453-1468. ISSN 0305-750X. DOI 10.1016/j.worlddev.2007.06.023.

[12] Ellis, F. and Harris, N. (2004) "Development patterns, mobility and livelihood diversification", Keynote Paper for DFID Sustainable Development Retreat, University of Surrey, Guildford, UK. [Online]. Available: http://citeseerx.ist.psu.edu/viewdoc/download?doi=10.1.1.515.1085\&rep=rep1 \&type $=$ pdf [Accessed: 31 Jan. 2019].

[13] Fafchamps, M. and Minten, B. (1998) "Returns to social capital among traders", International Food Policy Research Institute (IFPRI) Discussion Paper, (23). [Online]. Available: https://ageconsearch. umn.edu/record/91851/files/pubs_divs_mtid_dp_papers_dp23.pdf [Accessed: 31 Jan. 2019]. 
[14] Huber, C. (2013) "Generalized structural equation modeling using stata", Presented at the Italian Stata Users Group Meeting, November 14-15.

[15] Huber, C. (2014) "Introduction to Structural Equation Modeling Using Stata", California Association for Institutional Research.

[16] Hulme, D. and Shepherd, A. (2003) "Conceptualizing chronic poverty", World Development, Vol. 31, No. 3, pp. 403-423. ISSN 0305-750X. DOI 10.1016/S0305-750X(02)00222-X.

[17] Lanjouw, J. O. and Lanjouw, P. (2001) "The rural non-farm sector: issues and evidence from developing countries", Agricultural Economics, Vol. 26, No. 1, pp. 1-23. E-ISSN 1574-0862, ISSN 0169-5150. DOI 10.1111/j.1574-0862.2001.tb00051.x.

[18] Liu, J. E., Dai, H., Li, M. and Li, M. S. (2018) "Personal networks and employment: a study on landless farmers in Yunnan province of China", Asia Pacific Journal of Social Work and Development, Vol. 28, No. 2, pp. 71-83. E-ISSN 2165-0993, ISSN 0218-5385. DOI 10.1080/02185385.2017.1408029.

[19] Liu, Z. and Liu, L. (2016) "Characteristics and driving factors of rural livelihood transition in the east coastal region of China: A case study of suburban Shanghai", Journal of Rural Studies, Vol. 43, pp. 145-158. ISSN 0743-0167. DOI 10.1016/j.jrurstud.2015.12.008.

[20] Martin, S. M. and Lorenzen, K. (2016) "Livelihood diversification in rural Laos", World Development, Vol. 83, pp. 231-243. ISSN 0305-750X. DOI 10.1016/j.worlddev.2016.01.018.

[21] Montgomery, J. D. (1991) "Social networks and persistent inequality in the labor market", Evanston: Center for Urban Affairs and Policy Research. [Online]. Available: https://www.ssc.wisc. edu/ jmontgom/socnetpersineq.pdf [Accessed: 31 Jan. 2019].

[22] Nee, V. (1996) "The emergence of a market society: Changing mechanisms of stratification in China", American Journal of Sociology, Vol. 101, No. 4, pp. 908-949. E-ISSN 1537-5390, ISSN 0002-9602. DOI 10.1086/230784.

[23] Newman, C. and Kinghan, C. (2015) "The rural non-farm economy", In Tarp, F. (ed.) "Growth, Structural Transformation and Rural Change in Viet Nam: A Rising Dragon on the Move", Oxford University Press. ISBN 97801-9879-6961. [Online]. Available: https://www.econstor.eu/bitstream/1 0419/162550/1/89081354X.pdf [Accessed: 31 Jan. 2019].

[24] Povel, F. (2015) "Measuring exposure to downside risk with an application to Thailand and Vietnam", World Development, Vol. 71, pp. 4-24. ISSN 0305-750X. DOI 10.1016/j.worlddev.2013.11.006.

[25] Ngo, Q.-T. (2018) "Individual-level employment transitions in rural Viet Nam", UNU-WIDER Working Paper, 154/2018.

[26] Reardon, T. (1997) "Using evidence of household income diversification to inform study of the rural nonfarm labor market in Africa", World Development, Vol. 25, No. 5, pp. 735-747. ISSN 0305-750X. DOI 10.1016/S0305-750X(96)00137-4.

[27] Reardon, T., Berdegué, J. and Escobar, G. (2001) "Rural nonfarm employment and incomes in Latin America: overview and policy implications", World Development, Vol. 29, No. 3, pp. 395-409. ISSN 0305-750X. DOI 10.1016/S0305-750X(00)00112-1.

[28] Rennings, K., Ziegler, A. and Zwick, T. (2001) "Employment changes in environmentally innovative firms", ZEW Discussion Paper No. 01-46, 24 p. DOI 10.2139/ssrn.329120.

[29] Rigg, J., Salamanca, A., Phongsiri, M. and Sripun, M. (2018) "More farmers, less farming? Understanding the truncated agrarian transition in Thailand", World Development, Vol. 107, pp. 327-337. ISSN 0305-750X. DOI 10.1016/j.worlddev.2018.03.008.

[30] Rozelle, S., Guo, L., Shen, M., Hughart, A. and Giles, J. (1999) "Leaving China"s farms: survey results of new paths and remaining hurdles to rural migration", The China Quarterly, Vol. 158, pp. 367-393. ISSN 0009-4439. DOI 10.1017/S0305741000005816.

[31] Sackey, H. A. (2018) "Rural Non-farm Employment in Ghana in an Era of Structural Transformation: Prevalence, Determinants, and Implications for Well-being", Journal of Rural and Community Development, Vol. 13, No. 3, pp. 57-77. ISSN 1712-8277. 
[32] Simoes, N., Crespo, N. and Moreira, S. B. (2016) "Individual determinants of self-employment entry: What do we really know?", Journal of Economic Surveys, Vol. 30, No. 4, pp. 783-806. ISSN 0950-0804 / 1467-6419. DOI 10.1111/joes.12111.

[33] Tarp, F. (2017) "Growth, Structural Transformation and Rural Change in Viet Nam: A Rising Dragon on the Move", Oxford University Press. ISBN 97801-9879-6961. DOI 10.1093/acprof:oso/9780198796961.001.0001.

[34] Ulrik, B. (2015) "Local transformation in rural Vietnam: A commune level analysis", WIDER Working Paper, No. 2015/065. ISSN 17987237. ISBN 97892-9230-9534. [Online]. Available: https://www.econstor.eu/bitstream/10419/126362/1/834311461.pdf [Accessed: 31 Jan. 2019].

[35] Walter, S. G. and Heinrichs, S. (2015) "Who becomes an entrepreneur? A 30-years-review of individual-level research", Journal of Small Business and Enterprise Development, Vol. 22, No. 2, pp. 225-248. ISSN 1462-6004. DOI 10.1108/JSBED-09-2012-0106.

[36] Wu, H. X. and Zhou, L. (1996) "Rural-to-Urban Migration in China", Asian-Pacific Economic Literature, Vol. 10, No. 2, pp. 54-67. ISSN 0818-9935. DOI 10.1111/j.1467-8411.1996.tb00016.x.

[37] Yaqub, S. (2000) "Poverty dynamics in developing countries", Brighton: Institute of Development Studies. ISBN 18-5864-2388. [Online]. Available: http://www.ophi.org.uk/wp-content/uploads/ ssYaqub-2000.pdf [Accessed: 31 Jan. 2019]. 